\title{
Insider Trading and Institutional Holdings in Mergers and Acquisitions
}

\author{
Ching-Chih Wu${ }^{*}$, Bing-Huei Lin, Tung-Hsiao Yang \\ Department of Finance, National Chung Hsing University, Taiwan
}

Copyright $(2018$ by authors, all rights reserved. Authors agree that this article remains permanently open access under the terms of the Creative Commons Attribution License 4.0 International License

\begin{abstract}
We investigate three issues about the impact of insider trades and institutional holdings on mergers and acquisitions (M\&As). First, we test how insider trades affect the trading behavior of institutional investors in M\&As. Second, we test whose trading behavior, either insiders or institutional investors, has greater explanatory power for the performance of M\&A firms after takeover announcements. Third, we analyze the industry-wide spillover effects of insider trades and institutional holdings. Empirically, we find that insiders and institutional investors of M\&A firms may utilize similar information in their transactions because insider trades induce similar trading behavior for institutional investors. In addition, insider trades, relative to institutional holdings, have greater explanatory power for M\&A firm's long-term performance. Finally, compared with insider trades, institutional holdings have a more significant spillover effect in the industry of M\&A firms.
\end{abstract}

Keywords Insider Trade, Institutional Holding, Spillover Effect, Contagion Effect

\section{Introduction}

Information asymmetry between managers and investors is a fundamental issue for investors and market observers. Some investors have information advantage relative to others and normally they would take advantage of these information sources to benefit themselves [1-8]. Even though the existing evidence supports weak form or semi-strong form market efficiency, it is not uncommon to find some investors have a better investment performance than others due to the information advantage. For example, many investors follow institutional holdings and insider trading activity to gain valuable insights, insiders and institutional investors are two types of investors that may have information advantages over other outside or retail investors [9-12]. In general, these two parties may share the same information sources and researchers utilize their trading behavior to forecast the firm's market performance after seasoned equity offerings (SEOs) [13-16]. We are interested in the behavior of informed traders in the M\&As.

In this study, we follow the previous literature by using the M\&As to analyze the trading behavior of insiders and institutional investors [17-20]. Some investigations have been carried out [21-26]. In addition, we also extend our research to the spillover effect of these two types of investors in the industries.

There are three research questions in this study. First, we test how insider trades affect the trading behavior of institutional investors in the M\&As. Some researchers, such as [13], find that insider and institutional trading influences the firms' information environment, but how the asset prices change depends on each group's relative information advantage. In addition, Luo[27] finds that managers of merging companies appear to extract information from the market reaction of institutional investors and later consider it in closing the deal. The author concludes that firms held by short-term institutional investors have a weaker bargaining position in acquisitions. Weaker monitoring from short-term institutional investors could allow managers to accept value-reducing acquisitions.

In contrast, Griffin[18] cannot find supportive evidence to show that institutional investors trade on the information from investment bank connections through takeover advising. Therefore, there is a research gap in the information flow between insiders and institutional investors. Our research fills in this gap and sheds light on this issue by utilizing M\&As and test how insider trades affect the institutional holding of these M\&As firms.

Second, due to the different characteristics of information sources, we test whose trading behavior, either insiders or institutional investors, has greater explanatory power for long-term performance after M\&As. Allen[28] finds that the trades of insiders are significantly related to post-spin-off stock returns, takeovers, and delistings of spin-off firms. This implies that the trading behaviors of insiders and institutional investors have different explanatory power for the takeover market performance. 
We measure the insider trades and the institutional holdings before and after M\&As and analyze the impact of the trading behavior of both groups on the long-term performance, which is measured by the buy-and-hold abnormal returns. This analysis contributes to the related literature of understanding the prediction power of informed traders on a firm's market performance after M\&As.

Third, we analyze the industry-wide spillover effect of insider trades and institutional holdings. In the M\&As, the insiders or institutional investors may signal some private information through their trading behaviors. How do insiders and institutional investors of other firms in the same industry react to these signals? Based on the existing evidence, we extend our analysis to the spillover effect of insider trades and institutional holdings on the institutional holdings of matching firms in the M\&As. The analysis helps to understand how insider trades and institutional holdings affect the reaction of institutional investors of firms in the same industry.

The empirical results show that insider transactions have a significant impact on the institutional holdings. First, we find that institutional investors significantly decrease holdings of acquiring firms as insider transactions with the negative net sell of insider transactions. This result implies that insiders and institutional investors apply a different source of information and they have a different point of views under negative net sell of insider transactions. Second, we find that insider transactions have greater explanatory power than institutional holdings for the long-term market performance of acquiring firms after M\&A announcements. In sum, we conclude that institutional investors share different information sources relative to insiders regarding M\&As. In addition, insider transactions have more explanatory power than institutional investors in the long-term market performance. Finally, we find that the insider transactions of acquiring firms have an insignificant impact on the adjustment of the institutional holdings of matching firms. Instead, we find that the institutional holdings of acquiring firms have a significant impact on the adjustment of institutional holdings of matching firms. This result implies that there exist spillover effects of institutional holdings on those matching firms' informed traders.

The main contribution of the research is to comprehensively analyze the reaction of insiders and institutional investors in the events of M\&As. The remainder of this paper is organized as follows. Section 2 briefly summarizes the relevant literature and develops our research hypotheses. In Section 3 and 4 we describe the methodology and data collection. Section 5 reports the results of the empirical analysis, while Section 6 concludes.

\section{Literature Review and Research Hypotheses}

Many studies have examined the trading behavior of insiders and institutional investors, and both groups have information advantages relative to other outside and retail investors. There is limited research on the interaction between insiders and institutional investors. Frankel[9] examines how financial statement informativeness, analyst following, and news related to the information asymmetry between insiders and outsiders. They find that increased analyst following is associated with the reduced profitability of insider trades and reduced insider purchases. Luo[27] finds that the market reacting to an M\&A announcement predicts the likelihood of the consummation of the proposed deal, suggesting that "insiders learn from outsiders." Based on the result, we expect that informed traders, including insiders and institutional investors, adjust their stock holdings in the M\&As once they observe the other group's move.

Piotroski[13] tests how much firm-specific, market-level, and industry-level information is impounded into the firm's stock price. In their research, they find that different informed participants change the information environment and the stock price reflects the different information conveyed by various participants. Griffin[18] also employs broker-level trading data to systematically examine possible cases of connected trading. They show that neither brokerage house clients nor the brokerage houses themselves trade on inside information through the brokerage house associated with the information of M\&As. They suggest that institutional investors are reluctant to use inside information in traceable manners. From their results, we are interested in testing how the different informed investors change their holdings after observing the trading of other informed investors.

In contrast, Jegadeesh[17] examines the pattern and profitability of institutional trades around takeover announcements. The authors find that the trades of funds as a group, either before or after takeover announcements, are not profitable. However, funds whose main broker is also a target advisor are net buyers of target shares before announcements, and their pre-announcement trades are significantly profitable. Therefore, leakage of inside information from brokerages that advise the target is a significant source of funds' informational advantage. Consequently, we expect that institutional investors may utilize information from insiders by observing insider trading behavior. We test how the insider trades affect institutional holdings after M\&As. The first research hypothesis is as follows.

Hypothesis 1: Insider trading should have a substantial impact on institutional holdings after M\&As. Therefore, the trading behavior of insiders and institutional investors should be very similar around M\&As.

The existing literature shows that insiders and institutional investors play an important role in the firm's strategic decision. For example, Wahal[14] finds a positive relation between industry-adjusted expenditures for property, plant, and equipment (PP\&E) and research and 
development $(\mathrm{R} \& \mathrm{D})$ and the fraction of shares owned by institutional investors. In addition, the informed traders may also utilize their information advantage to benefit themselves in their trading. Gaspar[29] investigates how the investment horizon of a firm's institutional shareholders impacts the market for corporate control. In their study, they also show that both target firms and acquiring firms with passive institutional investors have worse merging benefits relative to those with active institutional investors. Andriosopoulos[30] investigates the impact of institutional ownership on UK M\&As. They find that institutional investors increase the likelihood of an M\&A to be a large, cross-border deal, opting for full control.

Moreover, institutional ownership concentration and foreign institutional ownership increase the likelihood of cross-border M\&As. In addition, they assess the influence of institutional shareholders' investment horizon and find that while the investment horizon has a negative influence in encouraging cross-border M\&As, the presence of long-term investors encourages larger M\&As. Finally, even after controlling for the 2007-08 financial crisis the market reacts negatively to the announcement of cross-border M\&As.

As per insiders, King[31] shows that Both British and US evidence presented in this article confirm that insiders achieve abnormal gains and, surprisingly, that these gains persist long after the disclosure of insider trading. Damodaran[32] shows that there is substantial evidence that insider trading is present around corporate announcements and that this insider trading is motivated by private information. They find that insiders buying (selling) after they receive favorable (unfavorable) appraisal news, especially for negative appraisals. Furthermore, positive (negative) appraisals and net insider buying (selling) elicit significant positive (negative) abnormal returns during the appraisal period. Aboody[5] finds that insider gains in R\&D-intensive firms are substantially larger than insider gains in firms without R\&D. Insiders also take advantage of information on planned changes in R\&D budgets.

Agrawal[20] examines open market stock trades by registered insiders in about 3700 targets of takeovers announced during 1988-2006 and in a control sample of non-targets, both during an 'informed' and a control period. Fich[33] shows that studies of institutional monitoring focus on the fraction of the firm held by institutions. They focus on the fraction of the institution's portfolio represented by the firm. In the context of acquisitions, they hypothesize that institutional monitoring will be greatest when the target firm represents a significant allocation of funds in the institution's portfolio.

On the other hand, Ang[34] finds that shareholders of 1,283 (or 17\%) target firms responded to the offer with negative market returns. These investors were disappointed at the offer, despite the price premium. In addition, Augustin[35] documents pervasive informed trading activity in equity options before the M\&A announcements.
About 25\% of takeovers have positive abnormal volumes. These volume patterns indicate that informed traders are likely using bullish directional strategies for the target and volatility strategies for the acquirer. Shams[36] investigates the patterns of directors' trades and returns around takeover announcements. They find that the pre-announcement net value (the difference between buy value and sell value) of directors' trading is positively related to acquirers' announcement period abnormal returns. Therefore, we expect that both insider trading and the change in institutional holdings have certain explanatory power for the firm's performance. The unanswered question is which groups of investors has greater explanatory power than the other. This is our second research question, and we construct the second research hypothesis based on it as follows.

Hypothesis 2: Insider trades and institutional investors have significantly explanatory power for the firm's long-term performance after M\&As.

Moreover, Shahrur[37] uses a sample of 816 diversifying takeovers from 1978 to 2003 to examine whether takeover announcements release negative information about the prospects of the acquirer's main industry. They find that rivals that are most similar to the acquirer (homogeneous rivals) experience significant negative cumulative abnormal returns (CAR) around takeover announcements. In contrast, Erwin[38] examines the extent to which announcements of open market share repurchase programs affect the valuation of competing firms in the same industry. On average, although firms announcing open market share repurchase programs experience a significantly positive stock price reaction at the announcement, portfolios of rival firms in the same industry experience a significant and contemporaneous negative stock price reaction. In other words, they show that open market repurchase announcements have an adverse effect on rivals in the same industry with the event firms.

Our research contributes to the related literature by analyzing the spillover effect of insider trading and the changes in institutional holdings between M\&A firms and non-M\&A firms. To the best of our knowledge, this is the first paper to analyze the spillover effect comprehensively in the M\&As. We construct the third research hypothesis as follows:

Hypothesis 3: There exists spillover effect of insider trading and institutional holdings of M\&A firms on non-M\&A firms in the same industry.

\section{Methodology}

In this study, we need to measure the characteristics of institutional holding, insider trading, and long-term market performance in empirical tests. Hence, we summarize these measures as follows. 


\subsection{Measuring Institutional Holding}

We use the number of shares held by institutions divided by the number of shares outstanding to calculate the percentage of institutional holdings for a sample firm.

\subsection{Measuring Insider Trading}

Previous studies measure insider trading in various ways. Gombola[39,40] observe the monthly number of insider transactions, number of shares, and dollar value around SEOs. Rozeff[41] employs insider trading deflated by trading volume (number of shares traded by insider over a number of shares traded in the market) to investigate the direction of insider trades along the value/glamour spectrum. Lakonishok[42] uses the ratio of net insider trading (number of insider purchases minus the number of insider sales) to total insider transactions over the past few months to examine the market reaction to insider trades. Due to the availability of insider trading data, we use the number of net selling shares (number of shares sold minus number of shares bought) over the number of shares outstanding to measure the behavior of insider trading, which is

$$
\mathrm{NSH}=(N S-N P) / \text { Outstanding shares, }
$$

where NSH is the number of net selling shares, NS is the number of shares sold by all insiders, and NP is the number of share purchased by all insiders.

In order to capture the asymmetric reaction to different insider trading, we decompose net selling into two components and create two variables to represent it. One is $\mathrm{PNSH}$, equal to the positive net selling when net selling is greater than zero, and zero otherwise. The other variable is $\mathrm{NNSH}$, equal to the negative net selling when net selling is less than zero, and zero otherwise.

\subsection{Measuring Long-Term Market Performance}

This study calculates the buy-and-hold abnormal returns of a stock i as follows:

$$
B H A R_{i}=\prod_{t=1}^{T}\left(1+R_{i, t}\right)-\prod_{t=1}^{T}\left(1+R_{\text {bench }, t}\right),
$$

where $R_{i, t}$ and $R_{\text {bench,t }}$, respectively, denote firm $j$ 's returns and benchmark returns on day $t$. We calculate BHAR starting from the announcement date of these events and set a month 22 trading days. If the firm is delisted, returns are compounding until the delist date.

Finally, the Compustat database provides all the accounting data we need for capturing the firm characteristics. Following previous studies, we add firm characteristic variables in the regression analysis, which include over-investment, the MB ratio, the firm size, and the debt ratio. We also control for year and industrial fixed effects in our regression analysis. Finally, to alleviate the effect of outliers in the following analysis, we winsorize all independent variables at $1 \%$ level.

\subsection{Empirical Models}

There are two parts to the empirical analysis in this study. First is the basic summary statistics for insider trading and institutional holdings. We summarize insider trades and institutional holdings in the different period before and after M\&As. In the univariate analysis, we expect to observe the basic statistics of these two measures and check the systematic pattern of these two measures. Second, we perform the multivariate analysis by running the regressions of the level of institutional holdings, and long-term market performance of M\&A firms. In addition, we also apply the regression analysis on the spillover effect and check how the non-M\&A firms react to the trading of insiders and institutional investors of M\&A firms.

To test the first hypothesis, we summarize the basic statistics for the change in institutional holdings concerning different insider trading in the M\&As and check the significance of the change of institutional holdings. To check the robustness of our results, in the multivariate regression analysis, we run the regression of institutional holdings on insider trades and control for all firm characteristics. The empirical model is as fol1ows:

$$
\begin{gathered}
I N S T H=\alpha+\beta_{1} P N S H+\beta_{2} N N S H+\beta_{3} \text { OVERINV }+ \\
\beta_{4} B M+\beta_{5} S I Z E+\beta_{6} D R+\beta_{6} R U N U P+\varepsilon_{I N S T H}
\end{gathered}
$$

where the dependent variable INSTH is the institutional holding for a firm, PNSH denotes the positive insider net selling, NNSH is the negative insider net selling, OVERINV is the capital expenditure over the expected level based on the estimation model in [43], BM is the book-to-market ratio, SIZE is the natural log of the firm's market capitalization, DR is the ratio of long-term debt to total assets, and RUNUP is the buy-and-hold abnormal return in three months before M\&As. In addition, we also control for industrial and year dummies in regression analysis.

Next, we measure the long-term market performance by three-year buy-and-hold abnormal return after M\&As. We sort the BHAR based on different time periods and then summarize the statistics of insider trading and institutional holdings. We also perform the multivariate analysis of the long-term market reactions. The empirical model is

$B H A R(0, t)=\alpha+\beta_{1} \varepsilon_{I N S T}+\beta_{2} P N S H+\beta_{3} N N S H+$ $\beta_{4}$ OVERINV $+\beta_{5} B M+\beta_{6} S I Z E+\beta_{7} D R+$ $\beta_{8} R U N U P+\varepsilon$,

where $\operatorname{BHAR}(0, \mathrm{t})$ is the t-year buy-and-hold abnormal returns of a stock $\mathrm{i}, \varepsilon_{I N S T H}$ is the residual of the institutional holding in the previous regression of institutional holdings. Based on the result of (3), there may have endogenous problems because the insider trading may affect the change of institutional holdings. To alleviate the endogenous problem, we utilize two-stage least square in the regression of (4).

Finally, we test the spillover effect of insider trading and the change of institutional holding on the institutional 
holding of matching firms in the same industry. To measure the spillover effect, we measure the insider trading and the change of institutional holdings for matching firms. In the analysis of summary statistics, we check the basic statistics of insider trading and the change of institutional holdings for matching firms. In addition, we perform the multivariate regression analysis, and the empirical models are as follows:

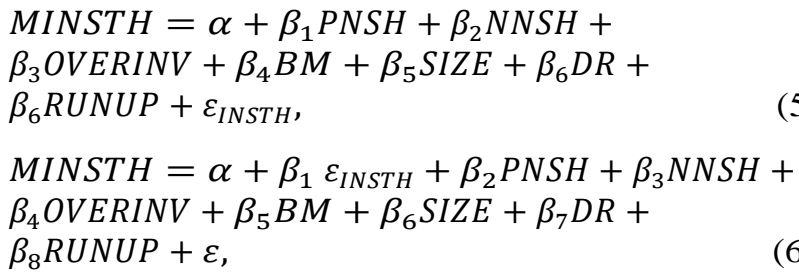

$M I N S T H=\alpha+\beta_{1} \varepsilon_{I N S T H}+\beta_{2} P N S H+\beta_{3} N N S H+$ $\beta_{4}$ OVERINV $+\beta_{5} B M+\beta_{6} S I Z E+\beta_{7} D R+$ $\beta_{8} R U N U P+\varepsilon$,

where MINSTH is the institutional holdings of matching firms. If the spillover effect exists, then we expect that the coefficients of $\beta_{1}$ or $\beta_{2}$ in (5) and of $\beta_{1}, \beta_{2}$ or $\beta_{3}$ in (6) would be significant.

\section{Data and Sample Characteristics}

All sample firms are collected from the Thomson Financial Securities Data Corporation (SDC) Domestic M\&A Database with a transaction value of at least US $\$ 50$ million. M\&A characteristics, including the announcement date, the company identity, and we collect a sample covering the period from 1990 to 2010 and trace their returns up to 2013 and in a control sample of non-M\&A firms. The sample firm's CUSIP can be matched with the Center for Research in Securities Prices (CRSP) data. To be included in our sample, the observations must meet the following criteria:

1. The M\&As must be common stocks of firms (share codes 10 and 11) listed on NYSE, AMEX, and NASDAQ. American depository receipts (ADRs), real estate investment trusts (REITs), closed-end mutual funds, and partnership are eliminated from the sample.

2. As in other previous studies, we exclude M\&As of the financial and regulated utility industries (SIC codes 6000-6999 and 4900-4999 respectively) since firms in these industries have to meet regulatory requirements in making the strategic decisions. Also, accounting items of these two industries are distinct from those of other industries.

3. A firm included in the SEO events cannot be in the M\&A sample within the three years before and after M\&As since the long-term performance may arise from SEOs rather than M\&As.

We collect daily returns and number of shares outstanding of the sample firms and daily market indices (CRSP VW and EW) from the CRSP database. Annual accounting data of firm-specific variables are collected from the Compustat database. In addition, we collect monthly insider trading data from the Thomson CDA Investnet database, and quarterly institutional equity holdings from the Thomson CDA Spectrum database, which include the data from the $13 \mathrm{~F}$ filings. We use the institutional codes in the CDA Spectrum database to identify the types of institutional investors. ${ }^{1}$ The firm characteristics may have a certain pattern that drives firms to conduct equity financing. We summarize the firm characteristics in Table 1.

This table provides summary statistics of M\&A firms from 1990 to 2010, and the number of M\&A firms is 10,203 . The variables are defined as follow. SIZE is the market value of equity on the 11th day before the M\&A announcement day. BM is the book-to-market ratio at the end of the month preceding M\&A. RUNUP is the buy-and-hold abnormal return in the three months before the M\&A announcement. BHAR is the buy-and-hold abnormal return for three years after M\&As. OVERINV is the capital expenditure over the expected level based on the estimation model in [43]. DR is the ratio of long-term debt to total assets.

This table provides summary statistics of sample firms from 1990 to 2010. The variables are defined as follow. SIZE is the market value of equity on the 11th day prior to the event announcement day. BM is the book-to-market ratio at the end of the month preceding the specific corporate events. RUNUP is the buy-and-hold abnormal return in the three months before the specific corporate events announcement. BHAR is the buy-and-hold abnormal return for three years after the specific corporate events. OVERINV is the capital expenditure over the expected level based on the estimation model in [43]. DR is the ratio of long-run debt to total assets.

In general, significant operational advantages can be obtained when two firms are combined. In fact, the goal of most M\&As is to improve company performance and shareholder value over the long-term. Meanwhile, investors may expect stock price of M\&As goes up dramatically by company government goal of M\&A firms. In contrast, previous research like Andre[44] suggests that significantly underperform over the three-year post-event period of M\&A firms. From Table 1, we find that the long-term market performance, however, is poor in these M\&A firms, which is consistent with existing empirical evidence. In addition, the investment level is over the expected level, which implies that these firms have aggressive investment strategies. Overall, M\&A firms perform poorly, and they tend to over invest.

1 Institutional investors with more than $\$ 100$ million in equities mus report their equity ownership to the SEC in quarterly $13 \mathrm{~F}$ filings. The CDA Spectrum classifies institutional investors of five types: bank (trust departments), insurance companies, investment companies (mutual funds and closed-end funds), independent investment advisors (principally pension fund advisors), and others (miscellaneous institutions such as endowment funds or public pension funds). 
Table 1. Summary statistics for firm characteristics of M\&As

\begin{tabular}{ccccccc}
\hline & $\begin{array}{c}\text { SIZE } \\
(\text { In \$) }\end{array}$ & BM & $\begin{array}{c}\text { RUNUP } \\
\text { (3months) }\end{array}$ & $\begin{array}{c}\text { BHAR } \\
\text { (3 years) }\end{array}$ & OVERINV & DR \\
\hline Mean & 8.279 & 0.538 & 0.037 & -0.023 & 0.036 & 0.174 \\
\hline Median & 5.948 & 0.434 & 0 & -0.189 & 0.014 & 0.135 \\
\hline Std & 9.797 & 0.443 & 0.335 & 1.351 & 0.14 & 0.178 \\
\hline Q1 & 4.536 & 0.27 & -0.118 & -0.652 & -0.033 & 0.008 \\
\hline Q3 & 7.322 & 0.677 & 0.132 & 0.298 & 0.084 & 0.282 \\
\hline
\end{tabular}

\section{Empirical Results}

We analyze the institutional holdings before and after M\&As. The institutional holdings of four quarters before and after M\&As are summarized in Table 2.

Table 2. Median and mean of the institutional holding of M\&As

\begin{tabular}{ccc}
\hline Quarter & Mean & Median \\
\hline-4 & 0.491 & 0.515 \\
\hline-3 & 0.495 & 0.523 \\
\hline-2 & 0.499 & 0.527 \\
\hline-1 & 0.504 & 0.529 \\
\hline 1 & 0.503 & 0.532 \\
\hline 3 & 0.506 & 0.536 \\
\hline 4 & 0.508 & 0.541 \\
\hline
\end{tabular}

The median and mean of both measures of institutional holdings are calculated on a quarterly basis which is the frequency in the database. The effective date of each M\&A is in Quarter 1 and the first quarter before the effective date is Quarter -1. The number of the company of M\&As are 8,811 in Quarter 1.

The median of institutional ownership is calculated under a quarterly basis which is the frequency in the database. The effective date of each event is in Quarter 1 and the first quarter before the effective date is Quarter - 1 .

From the results in Table 2, we find that the institutional investors increase their holding substantially before and after M\&As, which implies that institutional investors do change their holdings after M\&As. Whether these changes is correlated with firms' operational performance is a key question about the information sources of the information advantage for institutional investors. We summarize the operational performance in Table 3.

We measure the firm's operational performance from EBIT/Sales and ROA. The effective date is in year 0, and the median and mean of both measures are under annual basis. We collect the data for three years before and after M\&As.

We measure the firm's operational performance from EBIT/Sales and ROA. The effective date is in year 1, and the median and mean of both measures are under annual basis. We collect the data for three years before and after the specific events.

From the results in Table 3, we find that the operational performance does not have obvious improvement after M\&As. The Median of EBIT/sales improves in the current year of M\&As but gets back to the original level in the first year after M\&As. These results imply that institutional investors may not rely on the operational performance to adjust their holding of these sample firms. Next, we check the change of holding of insiders. This may be another information sources for institutional investors. We summarize the change of insider transactions in Table 4.

This study reports the median and mean cumulative insider trading from month -6 to month $t$ relative to the M\&A effective date. The number of observation of M\&As is 7,289 in the period $(-6,1)$. All numbers are a percentage of outstanding shares. Net sell is the difference between insider sell and insider purchase.

We report the median and mean cumulative insider trading from month -6 to month $t$ relative to the specific events' effective date. All numbers are a percentage of outstanding shares of all sample firms. Net sell is the difference between insider sell and insider purchase.

From the results in Table 4, we find that while insiders increase their purchases below normal levels, they increase their sales, even more, thus increasing their net sales, i.e., insiders reduce their holding by degrees gradually before and after M\&As, which implies that they may expect a not better results somewhat after M\&As for M\&A firms. Based on this result, we suspect that insiders are pessimistic in the M\&As. To analyze whether the insider transactions have a significant impact on the adjustment of institutional holdings, we regress the institutional holdings on the net sell of insider transactions and control for other firm characteristics. The results are summarized in Table 5 
Table 3. Operational performance of sample firms of M\&As

\begin{tabular}{cccccccccc}
\hline & & \multicolumn{9}{c}{ Year } \\
\cline { 3 - 8 } Variable & & -3 & -2 & -1 & 0 & 1 & 2 & 3 \\
\hline EBIT/Sales & Median & 0.127 & 0.129 & 0.131 & 0.129 & 0.126 & 0.125 & 0.124 \\
\hline & Mean & 0.053 & 0.054 & 0.055 & 0.047 & 0.046 & 0.043 & 0.044 \\
\hline ROA & Median & -0.236 & -0.032 & 0.062 & -0.014 & 0.044 & 0.001 & -0.300 \\
\hline & Mean & 0.022 & 0.038 & 0.041 & 0.021 & 0.011 & -0.080 & 0.013 \\
\hline
\end{tabular}

Table 4. Median and mean of insider transactions of M\&As

\begin{tabular}{ccccccc}
\hline & & & & \multicolumn{2}{c}{ Mean } \\
\hline Period & Sell & Purchase & Net sell & Sell & Purchase & Net sell \\
\hline$(-6,-3)$ & 0.0001 & 0.0001 & 0.0000 & 0.0017 & 0.0007 & 0.0010 \\
\hline$(-6,-2)$ & 0.0001 & 0.0001 & 0.0000 & 0.0019 & 0.0008 & 0.0011 \\
\hline$(-6,-1)$ & 0.0001 & 0.0001 & 0.0000 & 0.0022 & 0.0009 & 0.0013 \\
\hline$(-6,1)$ & 0.0002 & 0.0002 & 0.0000 & 0.0027 & 0.0013 & 0.0013 \\
\hline$(-6,2)$ & 0.0002 & 0.0002 & 0.0000 & 0.0028 & 0.0014 & 0.0014 \\
\hline$(-6,3)$ & 0.0003 & 0.0002 & 0.0000 & 0.0034 & 0.0015 & 0.0019 \\
\hline$(-6,6)$ & 0.0004 & 0.0003 & 0.0000 & 0.0037 & 0.0018 & 0.0019 \\
\hline$(-6,12)$ & 0.0006 & 0.0005 & 0.0000 & 0.0049 & 0.0024 & 0.0025 \\
\hline$(-6,24)$ & 0.0010 & 0.0009 & 0.0000 & 0.0061 & 0.0036 & 0.0025 \\
\hline$(-1,1)$ & 0.0000 & 0.0001 & 0.0000 & 0.0013 & 0.0008 & 0.0005 \\
\hline
\end{tabular}

Table 5. Impact of insider trades on the institutional holding of M\&As

\begin{tabular}{|c|c|c|c|}
\hline Variables & (1) & (2) & (3) \\
\hline \multirow[t]{2}{*}{ PNSH } & 0.247 & 0.250 & 0.218 \\
\hline & $(0.198)$ & $(0.196)$ & $(0.259)$ \\
\hline \multirow[t]{2}{*}{$\mathrm{NNSH}$} & $0.890^{* *}$ & $0.812^{* *}$ & $0.813^{* *}$ \\
\hline & $(0.013)$ & $(0.044)$ & $(0.025)$ \\
\hline \multirow[t]{2}{*}{ OVERINV } & $0.063 * * *$ & $0.072 * * *$ & $0.071^{* * *}$ \\
\hline & $(0.000)$ & $(0.000)$ & $(0.000)$ \\
\hline \multirow[t]{2}{*}{$\mathrm{BM}$} & $0.070 * * *$ & $0.047 * * *$ & $0.051 * * *$ \\
\hline & $(0.000)$ & $(0.000)$ & $(0.000)$ \\
\hline \multirow[t]{2}{*}{ SIZE } & $0.069 * * *$ & $0.058^{* * *}$ & $0.064^{* * *}$ \\
\hline & $(0.000)$ & $(0.000)$ & $(0.000)$ \\
\hline \multirow[t]{2}{*}{ DR } & $0.024^{* *}$ & $0.046^{* * *}$ & $0.099 * * *$ \\
\hline & $(0.037)$ & $(0.000)$ & $(0.000)$ \\
\hline \multirow[t]{2}{*}{ RUNUP } & $-0.014 * *$ & $-0.021 * * *$ & $-0.019 * * *$ \\
\hline & $(0.042)$ & $(0.001)$ & $(0.003)$ \\
\hline \multirow[t]{2}{*}{ Constant } & $0.042 * * *$ & $0.030 * *$ & -0.011 \\
\hline & $(0.000)$ & $(0.021)$ & $(0.409)$ \\
\hline Observations & 12,887 & 12,887 & 12,887 \\
\hline Year dummy & No & Yes & Yes \\
\hline Industry dummy & No & No & Yes \\
\hline Adjusted R-squared & 0.317 & 0.376 & 0.426 \\
\hline
\end{tabular}


We suspect that there is an asymmetrical impact of insider transactions on institutional holding, and therefore we create the variables of PNSH and NNSH from insider net sell of M\&As. PNSH denotes the positive net sell of insider transactions when the net sell is greater than zero, and zero otherwise, NNSH is the negative insider net sell of insider transactions when the net sell is less than zero, and zero otherwise, and net sell is the difference between insider sell and insider purchase. The other variables of M\&As are defined as follows. BM is the book-to-market ratio. SIZE is the natural log of the firm's market capitalization. DR is the ratio of long-term debt to total assets. RUNUP is the buy-and-hold abnormal return in three months before M\&As. OVERINV is the capital expenditure over the expected level based on the estimation model in [43]. The numbers in parentheses are robust p-values. $* * *, * *, *$ represent the significance under $1 \%$, $5 \%, 10 \%$ level respectively.

The dependent variable is the institutional holding of acquiring firms in M\&As, and the independent variables are defined as follows. PNSH denotes the positive net sell of insider transactions when the net sell is greater than zero, and zero otherwise, NNSH is the negative insider net sell of insider transactions when the net sell is less than zero, and zero otherwise, and net sell is the difference between insider sell and insider purchase of M\&As. BM is the book-to-market ratio. SIZE is the natural log of the firm's market capitalization. DR is the ratio of long-term debt to total assets. RUNUP is the buy-and-hold abnormal return in three months before M\&As. OVERINV is the capital expenditure over the expected level based on the estimation model in [43]. The numbers in parentheses are robust p-values. $* * *, * *, *$ represent the significance under $1 \%, 5 \%, 10 \%$ level respectively.

The results in Table 5 support our expectation that the negative net sell of insider transactions have a significant impact on the adjustment of institutional holdings, but the positive net sell does not. Among the M\&As, institutional holdings decrease with the negative net sell of insider transactions. This result implies that insiders and institutional investors apply a different source of information and they have a different point of views under negative net sell of insider transactions regarding M\&As. Base on the empirical evidence, we expect that both insiders and institutional investors share similar information about these M\&A firms. Therefore, they show the same trading behavior after M\&As. Next, we analyze the impact of institutional investors or insider transactions on a firm's long-term market performance. The regression result is summarized in Table 6.

Table 6. Long-term performance of sample firms of M\&As

\begin{tabular}{|c|c|c|c|}
\hline Variables & (1) & (2) & (3) \\
\hline \multirow[t]{2}{*}{$\varepsilon_{\text {INSTH }}$} & -0.104 & -0.105 & -0.100 \\
\hline & $(0.114)$ & $(0.106)$ & $(0.123)$ \\
\hline \multirow[t]{2}{*}{ PNSH } & $3.525^{* * *}$ & $3.210^{* * *}$ & $3.037 * *$ \\
\hline & $(0.003)$ & $(0.009)$ & $(0.012)$ \\
\hline \multirow[t]{2}{*}{ NNSH } & $-8.404 * *$ & $-9.576 * *$ & $-10.475 * * *$ \\
\hline & $(0.037)$ & $(0.013)$ & $(0.007)$ \\
\hline \multirow[t]{2}{*}{ OVERINV } & 0.146 & 0.164 & 0.200 \\
\hline & $(0.257)$ & $(0.205)$ & $(0.153)$ \\
\hline \multirow[t]{2}{*}{$\mathrm{BM}$} & $0.335 * * *$ & $0.240^{* * *}$ & $0.287 * * *$ \\
\hline & $(0.000)$ & $(0.000)$ & $(0.000)$ \\
\hline \multirow[t]{2}{*}{ SIZE } & $0.012 * *$ & -0.009 & -0.011 \\
\hline & $(0.043)$ & $(0.157)$ & $(0.117)$ \\
\hline \multirow[t]{2}{*}{ DR } & -0.088 & $-0.161 * *$ & -0.107 \\
\hline & $(0.214)$ & $(0.021)$ & $(0.140)$ \\
\hline \multirow[t]{2}{*}{ RUNUP } & $-0.161 * * *$ & $-0.214 * * *$ & $-0.229 * * *$ \\
\hline & $(0.003)$ & $(0.000)$ & $(0.000)$ \\
\hline \multirow[t]{2}{*}{ Constant } & $-0.188 * * *$ & 0.128 & 0.117 \\
\hline & $(0.006)$ & $(0.201)$ & $(0.253)$ \\
\hline Observations & 11,166 & 11,166 & 11,166 \\
\hline Year dummy & No & Yes & Yes \\
\hline Industry dummy & No & No & Yes \\
\hline Adjusted R-squared & 0.011 & 0.042 & 0.053 \\
\hline
\end{tabular}


The dependent variable is three-year buy-and-hold abnormal returns. The independent variables are defined as follows. The $\varepsilon_{\text {INSTH }}$ is the residuals of institutional holding in the regression analysis in Table 5. PNSH denotes the positive net sell of insider transactions when the net sell is greater than zero, and zero otherwise, $\mathrm{NNSH}$ is the negative insider net sell of insider transactions when the net sell is less than zero, and zero otherwise, and net sell is the difference between insider sell and insider purchase of M\&As. BM is the book-to-market ratio. SIZE is the natural log of the firm's market capitalization. DR is the ratio of long-term debt to total assets. RUNUP is the buy-and-hold abnormal return in three months before M\&As. OVERINV is the capital expenditure over the expected level based on the estimation model in [43]. The numbers in parentheses are robust p-values. ***, **, * represent the significance under $1 \%, 5 \%, 10 \%$ level respectively.

From Table 6, we find that insider transactions, both positive insider net sell and negative insider net sell, have a significant impact on a firm's long-term performance in the M\&As. In the long run, despite insiders may adjust the portfolios of their assets with positive insider net sell of insider holdings, the long-term market performance is significant good. In addition, the institutional holdings also have a marginal significantly negative impact on a firm's long-term performance in M\&A firms. In sum, we conclude that institutional investors share different information sources relative to insider and insider transactions have strong explanatory power to the long-term market performance than institutional holding regarding M\&As. Furthermore, we analyze the impact of insider transactions of M\&As on the institutional holding of the matching firms. The regression result is summarized in Table 7.

We suspect that there is an asymmetric impact of insider transactions of M\&As on the institutional holding of matching firms. Therefore we create the variables of PNSH and NNSH from insider net sell of M\&As.

The dependent variable is the institutional holdings of matching firms. The independent variable PNSH denotes the positive net sell of insider transactions when the net sell is greater than zero, and zero otherwise, NNSH is the negative insider net sell of insider transactions when the net sell is less than zero, and zero otherwise, and net sell is the difference between insider sell and insider purchase of M\&As. The other variables of matching firms are defined as follows. BM is the book-to-market ratio. SIZE is the natural log of the firm's market capitalization. DR is the ratio of long-term debt to total assets. RUNUP is the buy-and-hold abnormal return in three months before SEOs. OVERINV is the capital expenditure over the expected level based on the estimation model in [43]. The numbers in parentheses are robust $\mathrm{p}$-values. ***, **, * represent the significance under $1 \%, 5 \%, 10 \%$ level respectively.

Table 7. The spillover effect of insider trades of M\&As

\begin{tabular}{|c|c|c|c|}
\hline Variables & (1) & (2) & (3) \\
\hline \multirow[t]{2}{*}{ PNSH } & 0.289 & 0.298 & 0.300 \\
\hline & $(0.213)$ & $(0.193)$ & $(0.187)$ \\
\hline \multirow[t]{2}{*}{ NNSH } & 0.388 & 0.303 & 0.312 \\
\hline & $(0.227)$ & $(0.421)$ & $(0.394)$ \\
\hline \multirow[t]{2}{*}{ OVERINV } & 0.025 & $0.040^{* *}$ & $0.036 * *$ \\
\hline & $(0.155)$ & $(0.020)$ & $(0.042)$ \\
\hline \multirow[t]{2}{*}{$\mathrm{BM}$} & $0.047 * * *$ & $0.022 * * *$ & $0.030 * * *$ \\
\hline & $(0.000)$ & $(0.001)$ & $(0.000)$ \\
\hline \multirow[t]{2}{*}{ SIZE } & $0.060 * * *$ & $0.049 * * *$ & $0.053 * * *$ \\
\hline & $(0.000)$ & $(0.000)$ & $(0.000)$ \\
\hline \multirow[t]{2}{*}{ DR } & -0.001 & $0.024 *$ & $0.067 * * *$ \\
\hline & $(0.968)$ & $(0.050)$ & $(0.000)$ \\
\hline \multirow[t]{2}{*}{ RUNUP } & $0.054 * * *$ & $0.045^{* * *}$ & $0.044 * * *$ \\
\hline & $(0.000)$ & $(0.000)$ & $(0.000)$ \\
\hline \multirow[t]{2}{*}{ Constant } & $0.081 * * *$ & $0.088^{* * *}$ & $0.056^{* * *}$ \\
\hline & $(0.000)$ & $(0.000)$ & $(0.000)$ \\
\hline Observations & 12,887 & 12,887 & 12,887 \\
\hline Year dummy & No & Yes & Yes \\
\hline Industry dummy & No & No & Yes \\
\hline Adjusted R-squared & 0.215 & 0.275 & 0.306 \\
\hline
\end{tabular}


The results in Table 7 show that the insider transactions of M\&As have not a significant impact on the adjustment of institutional holdings of matching firms. This result implies that institutional investors of matching firms and insiders of M\&As have a different point of views and they may refer to someone else with different information or the institutional investors of matching firms may be worse expected with none investment regarding M\&As. Finally, we analyze the impact of the institutional holding of M\&As on the institutional holding of matching firms. The regression result is summarized in Table 8 .

The dependent variable is the institutional holdings of matching firms. The independent variable INSTH is the institutional holding for an acquiring firm, and $\varepsilon_{\text {MINSTH }}$ is the residuals of the institutional holding of matching firms in the regression analysis in Table 7. PNSH denotes the positive net sell of insider transactions when the net sell is greater than zero, and zero otherwise, NNSH is the negative insider net sell of insider transactions when the net sell is less than zero, and zero otherwise, and net sell is the difference between insider sell and insider purchase of
M\&As. The other variables are defined as follows. BM is the book-to-market ratio. SIZE is the natural log of the firm's market capitalization. DR is the ratio of long-term debt to total assets. RUNUP is the buy-and-hold abnormal return in three months before M\&As. OVERINV is the capital expenditure over the expected level based on the estimation model in [43]. The numbers in parentheses are robust p-values. $* * *, * *, *$ represent the significance under $1 \%, 5 \%, 10 \%$ level respectively.

From Table 8, we find no evidence that insider transactions of M\&As have a significant impact on the adjustment of institutional holdings of matching firms; instead, we find that the institutional holdings of M\&As have a significant impact on the adjustment of institutional holdings of matching firms. Among the M\&As, the institutional holdings of matching firms increase or decrease the same direction with institutional holdings of M\&As. This result implies that institutional investors of M\&A firms have stronger spillover effect than insiders in our sample. This is an important finding in the related literature.

Table 8. Spillover effect of insider trades and institutional holding on the institutional holding of M\&As

\begin{tabular}{|c|c|c|c|c|}
\hline Variables & $(1)$ & $(2)$ & (3) & (4) \\
\hline \multirow[t]{2}{*}{ INSTH } & $0.580 * * *$ & $0.534 * * *$ & $0.514 * * *$ & \\
\hline & $(0.000)$ & $(0.000)$ & $(0.000)$ & \\
\hline \multirow[t]{2}{*}{$\varepsilon_{\text {MINSTH }}$} & & & & $0.514^{* * *}$ \\
\hline & & & & $(0.000)$ \\
\hline \multirow[t]{2}{*}{ PNSH } & & & & 0.300 \\
\hline & & & & $(0.151)$ \\
\hline \multirow[t]{2}{*}{ NNSH } & & & & 0.312 \\
\hline & & & & $(0.204)$ \\
\hline \multirow[t]{2}{*}{ OVERINV } & -0.011 & 0.002 & -0.001 & $0.036 * *$ \\
\hline & $(0.460)$ & $(0.910)$ & $(0.964)$ & $(0.019)$ \\
\hline \multirow[t]{2}{*}{$\mathrm{BM}$} & 0.007 & -0.003 & 0.003 & $0.030 * * *$ \\
\hline & $(0.312)$ & $(0.708)$ & $(0.635)$ & $(0.000)$ \\
\hline \multirow[t]{2}{*}{ SIZE } & $0.020^{* * *}$ & $0.018^{* * *}$ & $0.020^{* * *}$ & $0.053^{* * *}$ \\
\hline & $(0.000)$ & $(0.000)$ & $(0.000)$ & $(0.000)$ \\
\hline \multirow[t]{2}{*}{ DR } & -0.015 & -0.001 & 0.016 & $0.067 * * *$ \\
\hline & $(0.171)$ & $(0.949)$ & $(0.166)$ & $(0.000)$ \\
\hline \multirow[t]{2}{*}{ RUNUP } & $0.062 * * *$ & $0.056 * * *$ & $0.054 * * *$ & $0.044^{* * *}$ \\
\hline & $(0.000)$ & $(0.000)$ & $(0.000)$ & $(0.000)$ \\
\hline \multirow[t]{2}{*}{ Constant } & $0.057 * * *$ & $0.072 * * *$ & $0.062 * * *$ & $0.056^{* * *}$ \\
\hline & $(0.000)$ & $(0.000)$ & $(0.000)$ & $(0.000)$ \\
\hline Observations & 12,887 & 12,887 & 12,887 & 12,887 \\
\hline Year dummy & No & Yes & Yes & Yes \\
\hline Industry dummy & No & No & Yes & Yes \\
\hline Adjusted R-squared & 0.414 & 0.429 & 0.437 & 0.437 \\
\hline
\end{tabular}




\section{Conclusions}

The empirical results show that insider transactions have a significant impact on the institutional holdings. First, we find that institutional investors significantly decrease holdings of acquiring firms as insider transactions with the negative net sell of insider transactions. This result implies that insiders and institutional investors may utilize a different source of information and they have a different point of views regarding future performance after M\&As. Second, we find that insider transactions have greater explanatory power than institutional holdings for the long-term market performance of acquiring firms after the M\&As announcements. One of the reasons is that insiders have an informational advantage relative to institutional investors. This result is consistent with the existing evidence of the violation of strong-form efficient market hypothesis.

Finally, we find that the institutional holdings of acquiring firms have a significant impact on the adjustment of institutional holdings of non-M\&A matching firms. This result implies that there exist spillover effects of institutional holdings on those informed traders of non-M\&A matching firms in the M\&As. This result is consistent with the existing evidence of herding behavior among institutional investors. These institutional investors may share similar information sources for a specific industry or firms, which results in similar trading behavior. Insiders, in contrast, who have private information may not share with insiders of other firms. Therefore, we do not find the spillover effect in insider transactions.

The main contribution of the research is to comprehensively analyze the reaction of insiders and institutional investors in the M\&As. In addition, through the analysis of the spillover effect of the trading behavior informed traders, we find how institutional investors of non-M\&A matching firms react to the signals conveyed by insiders and institutional investors of M\&A firms. To the best of our knowledge, this is the first paper that addresses the spillover effect of informed traders in the financial market.

\section{REFERENCES}

[1] G. Ackerloff. The market for lemons: Quality uncertainty and the market mechanism, Quarterly Journal of Economics, Vol. 84, No. 3, pp. 488-500, 1970.

[2] R. Chiang, P. Venkatesh. Insider holdings and perceptions of information asymmetry: A note, The journal of finance, Vol. 43, No. 4, pp. 1041-1048, 1988.

[3] C. Marquardt, C. I. Wiedman. Voluntary disclosure, information asymmetry, and insider selling through secondary equity offerings, Contemporary Accounting Research, Vol. 15, No. 4, pp. 505-537, 1998.
[4] C. F. Noe. Voluntary disclosures and insider transactions, Journal of Accounting and Economics, Vol. 27, No. 3, pp. 305-326. 1999.

[5] D. Aboody, B. Lev. Information Asymmetry, R\&D, and Insider Gains, The Journal of Finance, Vol. 55, No. 6, pp. 2747-2766, 2000.

[6] G. Dell'Ariccia, R. Marquez. Information and bank credit allocation, Journal of Financial Economics, Vol. 72, No. 1, pp. 185-214, 2004.

[7] V. R. Eleswarapu, R. Thompson, K. Venkataraman. The impact of Regulation Fair Disclosure: Trading costs and information asymmetry, Journal of Financial and Quantitative Analysis, Vol. 39, No. 2, pp. 209-225, 2004.

[8] P. Draper, K. Paudyal. Information Asymmetry and Bidders' Gains, Journal of Business Finance \& Accounting, Vol. 35, No. 3-4, pp. 376-405, 2008

[9] R. Frankel, X. Li. Characteristics of a firm's information environment and the information asymmetry between insiders and outsiders, Journal of Accounting and Economics, Vol. 37, No. 2, pp. 229-259, 2004.

[10] M. R. Huson, G. MacKinnon. Corporate spinoffs and information asymmetry between investors, Journal of Corporate Finance, Vol. 9, No. 4, pp. 481-503, 2003.

[11] B. Baik, J.-K. Kang, J.-M. Kim. Local institutional investors, information asymmetries, and equity returns, Journal of financial economics, Vol. 97, No. 1, pp. 81-106, 2010.

[12] H. Jiang. Institutional investors, intangible information, and the book-to-market effect, Journal of Financial Economics, Vol. 96, No. 1, pp. 98-126, 2010.

[13] J. D. Piotroski, D. T. Roulstone. The influence of analysts, institutional investors, and insiders on the incorporation of market, industry, and firm-specific information into stock prices, The Accounting Review, Vol. 79, No. 4, pp. 1119-1151, 2004.

[14] S. Wahal, J. J. McConnell. Do institutional investors exacerbate managerial myopia? Journal of Corporate Finance, Vol. 6, No. 3, pp. 307-329, 2000.

[15] M. A. Ferreira, P. Matos. The colors of investors' money: The role of institutional investors around the world, Journal of Financial Economics, Vol. 88, No. 3, pp. 499-533, 2008.

[16] R. Aggarwal, I. Erel, M. Ferreira, P. Matos. Does governance travel around the world? Evidence from institutional investors, Journal of Financial Economics, Vol. 100, No. 1, pp. 154-181, 2011.

[17] N. Jegadeesh, Y. Tang. Institutional trades around takeover announcements: Skill vs. inside information, Working Paper, 2010.

[18] J. M. Griffin, T. Shu, S. Topaloglu. Examining the dark side of financial markets: Do institutions trade on information from investment bank connections? Review of Financial Studies, Vol. 25, No. 7, pp. 34, 2012.

[19] M. Harjoto, J. Garen. Inside ownership beyond the IPO: the evolution of corporate ownership concentration, Journal of Corporate Finance, Vol. 11, No. 4, pp. 661-679, 2005.

[20] A. Agrawal, T. Nasser. Insider trading in takeover targets, 
Journal of Corporate Finance, Vol. 18, No. 3, pp. 598-625, 2012.

[21] D. Bradley, X. Yuan. Information spillovers around seasoned equity offerings, Journal of Corporate Finance, Vol. 21, 106-118, 2013.

[22] A. Hameed, R. Morck, J. Shen, B. Yeung. Information, analysts, and stock return comovement, Review of Financial Studies, Vol. 28, No. 11, pp. 35, 2015.

[23] L. M. Benveniste, W. Y. Busaba, W. J. Wilhelm. Information externalities and the role of underwriters in primary equity markets, Journal of Financial Intermediation, Vol. 11, No. 1, pp. 61-86, 2002.

[24] L. M. Benveniste, A. Ljungqvist, W. J. Wilhelm, X. Yu. Evidence of information spillovers in the production of investment banking services, The Journal of Finance, Vol. 58, No. 2, pp. 577-608, 2003.

[25] M. B. Slovin, M. E. Sushka, J. A. Polonchek. Informational externalities of seasoned equity issues: differences between banks and industrial firms, Journal of Financial Economics, Vol. 32, No. 1, pp. 87-101, 1992.

[26] H. C. HSU, A. V. Reed, J. Rocholl. The new game in town: Competitive effects of IPOs, The Journal of Finance, Vol. 65, No. 2, pp. 495-528, 2010.

[27] Y. Luo. Do insiders learn from outsiders? Evidence from mergers and acquisitions, The Journal of Finance, Vol. 60, No. 4, pp. 1951-1982, 2005.

[28] J. W. Allen. Private Information and Spin-off Performance, The Journal of Business, Vol. 74, No. 2, pp. 281-306, 2001.

[29] J.-M. Gaspar, M. Massa, P. Matos. Shareholder investment horizons and the market for corporate control, Journal of financial economics, Vol. 76, No. 1, pp. 135-165, 2005.

[30] D. Andriosopoulos, S. Yang. The impact of institutional investors on mergers and acquisitions in the United Kingdom, Journal of Banking \& Finance, Vol. 50, 547-561, 2015.

[31] M. King, A. Roell, J. Kay, C. Wyplosz. Insider Trading, Economic Policy, Vol. 3, No. 6, pp. 163-193, 1988.

[32] A. Damodaran, C. H. Liu. Insider Trading as a Signal of Private Information, The Review of Financial Studies, Vol. 6, No. 1, pp. 79-119, 1993.
[33] E. M. Fich, J. Harford, A. L. Tran. Motivated monitors: The importance of institutional investors' portfolio weights, Journal of Financial Economics, Vol. 118, No. 1, pp. 21-48, 2015.

[34] J. S. Ang, A. K. Ismail. What premiums do target shareholders expect? Explaining negative returns upon offer announcements, Journal of Corporate Finance, Vol. 30, pp. 245-256, 2015.

[35] P. Augustin, M. Brenner, M. G. Subrahmanyam. Informed Options Trading prior to Takeover Announcements: Insider Trading? Working Paper, 2016.

[36] S. M. M. Shams, H. N. Duong, H. Singh. Information content of directors' trading around acquisitions, Pacific Basin Finance Journal, Vol. 38, pp. 177-193, 2016.

[37] H. Shahrur, A. Venkateswaran. Industry prospects and acquirer returns in diversifying takeovers, Journal of Financial Research, Vol. 32, No. 1, pp. 23-51, 2009.

[38] G. R. Erwin, J. M. Miller. The intra-industry effects of open market share repurchase: contagion or competitive? Journal of Financial Research, Vol. 21, No. 4, pp. 389-406, 1998.

[39] M. Gombola, H. W. Lee, F.-Y. Liu. Evidence of selling by managers after seasoned equity offering announcements, Financial Management, Vol. 26, No. 3, pp. 37-53, 1997.

[40] M. J. Gombola, H. W. Lee, F. Y. Liu. Further evidence on insider selling prior to seasoned equity offering announcements: The role of growth opportunities, Journal of Business Finance \& Accounting, Vol. 26, No. 5-6, pp. 621-649, 1999.

[41] M. S. Rozeff, M. A. Zaman. Overreaction and insider trading: Evidence from growth and value portfolios, The Journal of Finance, Vol. 53, No. 2, pp. 701-716, 1998.

[42] J. Lakonishok, I. Lee. Are insider trades informative? Review of financial studies, Vol. 14, No. 1, pp. 79-111, 2001.

[43] S. Richardson. Over-investment of free cash flow, Review of Accounting Studies, Vol. 11, No. 2-3, pp. 159-189, 2006.

[44] P. Andre, M. Kooli, J.-F. L'Her. The Long-Run Performance of Mergers and Acquisitions: Evidence from the Canadian Stock Market, Financial Management, Vol. 33, No. 4, pp. 27-43, 2004. 